\title{
Prognostic and predictive biomarkers for hypoxic regions on breast cancer: advances and challenges
}

\author{
Biomarcadores preditivos e prognósticos em regiōes hipóxicas do câncer de mama: \\ avanços e desafios
}

Moacyr Jesus Barreto de Melo Rêgo ; Eduardo Isidoro Carneiro Beltrão ${ }^{2}$

\begin{abstract}
Hypoxia has been extensively studied in solid tumors mainly in breast cancers and it is commonly associated with chemotherapy and radiotherapy resistance. Hypoxia inducible factor (HIF)-1 $\alpha$ is responsible for hypoxia in the tumor microenvironment and its molecular mechanisms as well as its therapeutic strategies have been described. However, a few investigations in the literature deal with its role in the hypoxic environment at diagnosis with the aim to guide therapeutic approaches. This study alerts researchers in pathology and oncology to the importance of assessing area extension as well as specific biomarkers, inasmuch as molecules reactive to hypoxia may indicate response to antiangiogenic therapy. The extension of hypoxic areas may alter the choice of therapeutic approach, insofar as some antiangiogenic treatments may considerably aggravate patient's clinical course since they create a hypoxic environment.
\end{abstract}

Keywords: hypoxia; carbonic anhydrase IX; hypoxia inducible factor; breast cancer diagnostic.

\section{INTRODUCTION}

Hypoxic response via hypoxia inducible factor (HIF) is acknowledged as one of the most important microenvironmental molecules as to tumor behavior. Not only does it influence all tumor features, but it also enables tumor cells to acquire an aggressive phenotype and ultimate resistance to chemotherapy and radiotherapy ${ }^{(11,21)}$. Several papers have described some cell hypoxia drawbacks such as poor drug delivery, namely cetuximab and transtuzumab on immunotherapy ${ }^{(19)}$, the impaired cellular uptake of many drugs caused by tumor associated acidity ${ }^{(9)}$, as well as the role of key-cascade hypoxia molecules in therapeutics ${ }^{(17)}$. Some mechanisms have been highlighted such as the HIF-1 $\alpha$ knockdown in MCF-7 breast carcinoma cells, which increases the sensitivity to methotrexate ${ }^{(20)}$. Furthermore, HIF- $1 \alpha$ silencing reverts the hypoxia-induced protection against paclitaxel-induced apoptosis in MDA-MB-231 cells ${ }^{(12)}$. However, HIF-1 $\alpha$ is commonly transcribed in normoxia and its levels are kept low by a rapid degradation process through the ubiquitin-proteasome system (Figure). This constitutive expression, diffuse staining and short half-time hinder its use as a prognostic and diagnostic biomarker ${ }^{(1)}$.

Unlike researches into the role of hypoxia in tumor behavior and treatment, fewer investigations have been carried out as to the role of hypoxia as prognostic and predictive information, which could be applied to guide therapeutic approaches. This is pivotal inasmuch as some breast cancer patients undergoing anti-angiogenic therapy show increased metastasis levels, possibly as a result of induced hypoxia ${ }^{(27)}$.

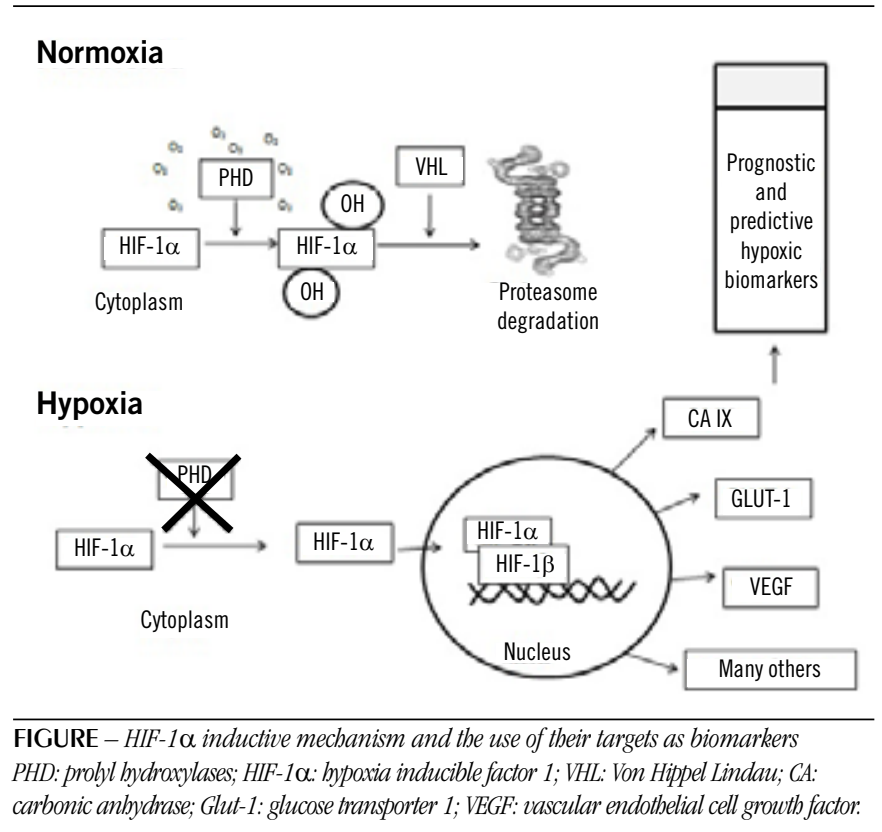

First submission on 17/04/12; last submission on $08 / 08 / 12$; accepted for publication on $03 / 12 / 12$; published on $20 / 02 / 13$

1. Doctor in Therapeutic Innovation by Universidade Federal de Pernambuco (UFPE); researcher from the Research Center for Therapeutic Innovation (NUPIT-UFPE).

2. Doctor in Biological Science by UFPE; adjunct professor at UFPE Biochemistry Department; researcher from the pathology sector of Keizo Asami Immunopathology Laboratory

by UFPE; chief of the Cancer Biomarker Research Group from Conselho Nacional de Desenvolvimento Científico e Tecnológico (CNPq). 
Voss and co-workers ${ }^{(8)}$ have recently demonstrated that hypoxia causes increased migratory activity in tumor cells, involving the release and autocrine action of soluble mediators. Hypoxic cells conditioned medium induced migration of normoxic cells in selected luminal and basal-like breast carcinoma cell lines, which might explain the reason why anti-angiogenic treatment may aggravate clinical course in some patients. This could be at least minimized by the evaluation of hypoxia extension in solid tumors at diagnosis. This could be crucial to oncologists. Do we have any good and reproducible markers in hypoxia? There are some known hypoxia responsive molecules such as glucose transporter 1 (Glut-1), carbonic anhydrase (CA) IX, CD105 and HIF-1 $\alpha$. CA IX would be the answer to the previous question. The prolonged half-life of CA IX implies that it would remain in the tumor whereas other proteins with a shorter half-life are no longer present, enabling the access to hypoxia regions in many solid tumors including breast carcinomas ${ }^{(25)}$. Following this line of research, Ahlskog and c0workers $^{(2)}$ developed a specific new human anti-CA IX antibody that is expected to be non-immunogenic in patients with cancer and it may also serve as a broadly applicable reagent for the non-invasive imaging of hypoxia and for drug delivery applications.

Some reports show that $25 \%-40 \%$ of invasive breast cancer samples score positively for hypoxia markers ${ }^{(23)}$. This is higher than the $20 \%$ of human epidermal growth factor receptor 2 (HER-2) ${ }^{(3)}$. Why not including a hypoxia marker in antibody panel to pathological evaluation? It is particularly worth mentioning that HER-2 is not used in the clinical routine due to its frequency but due to its predictive value, hence studies should be conducted for hypoxia markers. Furthermore, high HIF-1 $\alpha$ levels are associated with hormone receptor negativity. HER-2 over expression increased levels of vascular endothelial cell growth factor (VEGF), cyclo-oxygenase-2 (COX-2) and nuclear p53, indicating a close link between HIF-1 $\alpha$ and aggressive phenotypes in breast cancer ${ }^{(28)}$. Dale and co-workers ${ }^{(10)}$ described the presence of different HIF-1 $\alpha$ splice variants in human breast cancer and non-malignant tissue samples. By performing realtime quantitative polymerase chain reaction (PCR) of fresh frozen tissues, the authors demonstrated that the messenger ribonucleic acid (mRNA) levels of a specific splice variant termed HIF-1 $\alpha$ thymine, adenine, guanine (TAG) are associated with positive lymph node status, high tumor grade, negative estrogen and progesterone status, and poor metastasis-free survival in early breast cancer. The quantification of this variant could indicate the hypoxia extension.

Fox et al. ${ }^{(13)}$ analyzed the expression of prolyl hydroxylases (PHD) 1 , PHD2 and PHD3 with HIF-1 $\alpha$ and HIF-inducible genes (VEGF and CA IX) by immunohistochemistry using a tissue microarray approach in 211 patients. PHD1, PHD2 and PHD3 expressions were significantly increased after epirubicin therapy, suggesting that this kind of treatment increases signaling of HIF-1 $\alpha$ degradation. This study was the first to describe the correlation between prolyl hydroxilases and treatment. However, it should be taken into account that the authors assessed CA IX with their own score system and considered any stained membrane as positive indication of hypoxia regions. Our experience indicates that generally there are several CA IX foci with differential extension and this should be considered in staining evaluation of hypoxia areas.
Another point is that prolyl hydroxilases could provide pertinent information for the assessment of hypoxic regions at diagnosis since they are the proper 02 sensor and not Hif- $1 \alpha$. This is the first evidence that these enzymes are up-regulated on therapy, which raises several possibilities. However, there are other things to be considered. Could FIH (asparaginyl hydroxylase) be used as a diagnostic and treatment responsive marker to signal Hif- $1 \alpha^{(18)}$ degradation in hypoxia? The first step was taken by revealing that the cytoplasmic location of FIH is associated with an enhanced hypoxic response and a shorter survival rate in invasive breast cancer ${ }^{(26)}$. Nevertheless, a few months ago another study ${ }^{(15)}$ showed Hif$1 \alpha$ and FIH co-staining in peri-necrotic areas. Moreover, considering PHD results, it is evinced that the challenge persists.

Yet we cannot overlook the pivotal role of hypoxia in estrogen receptors. Hypoxia induces rapid estrogen receptor alpha $(\mathrm{ER} \alpha)$ protein degradation by a proteasome-mediated pathway in breast cancer cells, and it also regulates ER $\alpha$ at transcriptional level ${ }^{(22)}$, which may facilitate hormone insensitivity in the tumor microenvironment. The challenge remains. Which is the best hypoxia biomarker? Is there any or only one? Is CA IX the best choice? How can hypoxia positivity and its extension be evaluated? Based on that information, we believe that CA IX is the best option in spite of limited but invaluable information concerning this hypoxia marker in breast cancer ${ }^{(4,6)}$. But how can it be used? Clinical studies have demonstrated that the VEGF-neutralizing antibody Avastin (bevacizumab) and VEGF receptor tyrosine kinase inhibitors (sorafenib and sunitinib) show limited efficacy as anticancer treatments in breast cancer ${ }^{(13)}$. Although these agents typically produce inhibition of primary tumor growth, lasting responses are rare, with only a moderate increase in progression-free survival and little benefit in overall survival ${ }^{(5)}$. Additionally, when antiangiogenic agents are administered on an intermittent schedule, such as with sunitinib, tumor regrowth is sometimes seen during drug-free periods ${ }^{(7)}$ or upon discontinuation of the treatment ${ }^{(16)}$. In light of these limited clinical benefits demonstrated, a U.S. Food and Drug Administration (FDA) panel has recently recommended that the approval of bevacizumab for treatment of advanced breast cancer be revoked. Besides, this new hypoxia mechanism has been recently elucidated as cancer stem cell stimulator ${ }^{(24)}$. These data altogether reinforce the need for accurate biomarkers that indicate when a patient will benefit or not from an antiangiogenic therapy. Despite these doubts, oncologists should consider hypoxia extension and number of foci in tumor microenvironment observed by pathologists. The assessment of hypoxia area extension must be taken into consideration for the treatment choice with anti-angiogenic molecules. Before depriving the tumor of nutrients and oxygen, oncologists should take other aspects into account, inasmuch as depending on hypoxia extension such treatment may aggravate the patient's condition. Thus multidisciplinary studies mainly from the pathology and oncology areas are required in order to establish guidelines for hypoxia extension.

\section{ACKNOWLEDGMENTS}

We thank Professor Luiz Bezerra de Carvalho Junior for his critical review. 


\section{RESUMO}

A bipóxia vem sendo bastante estudada nos tumores sólidos, principalmente nos de mama, os quais são frequentemente responsáveis pela resistência a quimioterapia e radioterapia. 0 hypoxia inducible factor (HIF)-1 $\alpha$ éo principal responsável pela hipóxia no microambiente tumoral e seus mecanismos moleculares têm sido descritos, além de estratégias terapêuticas desenhadas para essa molécula. Porém, poucos estudos na literatura tratam do papel do microambiente hipóxico no momento do diagnóstico para colaborar com a conduta dos oncologistas. Este artigo alerta os pesquisadores em patologia e oncologia para que eles observem a importância da avaliação da extensão da área, bem como dos biomarcadores específicos para esse ambiente, já que moléculas responsivas à bipóxia podem ser indicativas de resposta à terapia antiangiogênica. A extensão das áreas hipóxicas pode mudar a decisão do oncologista na escolha da conduta terapêutica, visto que alguns tratamentos antiangiogênicos podem piorar consideravelmente a evolução clínica do paciente por criar um ambiente hipóxico.

Unitermos: bipóxia; anidrase carbônica IX; fator induzido por hipóxia; diagnóstico de câncer de mama.

\section{REFERENCES}

1. ADAMS, J. M. et al. HIF-1: a key mediator in hypoxia. Acta Physiol Hung, v. 96, p. 19-28, 2009.

2. AHLSKOG, J. K. J. et al. Human monoclonal antibodies targeting carbonic anhydrase IX for the molecular imaging of hypoxic regions in solid tumours. Br J Cancer, v. 101, p. 645-57, 2009.

3. AL-AHWAL, M. S. Her-2 positivity and correlations with other histopathologic features in breast cancer patients-hospital based study.J Pak Med Assoc, v. 56, p. $65-8,2006$.

4. BEKETIC-ORESKOVIC, L. et al. Prognostic significance of carbonic anhydrase IX (CA-IX), endoglin (CD105) and 8-hydroxy-2-deoxyguanosine (8-0HdG) in breast cancer patients. Pathol Oncol Res, v. 17, n. 3, p. 593-603, 2011.

5. BERGERS, G.; HANAHAN, D. Modes of resistance to anti-angiogenic therapy. Nat Rev Cancer, v. 8, p. 592-603, 2008.

6. BETOF, A. S. et al. Carbonic anhydrase IX is a predictive marker of doxorubicin resistance in early-stage breast cancer independent of HER2 and TOP2A amplification. Br J Cancer, v. 28, n. 106, p. 916-22, 2012.

7. BURSTEIN, H. J. et al. Phase II study of sunitinib malate, an oral multitargeted tyrosine kinase inhibitor, in patients with metastatic breast cancer previously treated with an anthracycline and a taxane. J Clin Oncol, v. 26, p. 1810-6, 2008.

8. CHEN, H. H.; SU, W. C.; LIN, P. W.; GUO, H. R.; LEE, W. Y. Hypoxia-inducible factor-1alpha correlates with MET and metastasis in node-negative breast cancer. Breast Cancer Res Treat, v. 103, p. 167-75, 2007.

9. COSSE, J. P.; MICHIELS, C. Tumour hypoxia affects the responsiveness of cancer cells to chemotherapy and promotes cancer progression, Anticancer Agents Med Chem, v. 8, p. 790-7, 2008.

10. DALES, J. F. et al. Hypoxia inducible factor la gene (HIF-1a) splice variants: potential prognostic biomarkers in breast cancer. BMC Medicine, v. 8, p. 44, 2010.

11. DOUBLIER, S. et al. HIF-1 activation induces doxorubicin resistance in MCF7 3-D spheroids via P-glycoprotein expression: a potential model of the chemo-resistance of invasive micropapillary carcinoma of the breast. BMC Cancer, v. 4, 2012.

12. FLAMANT, L.; NOTTE, A.; NINANE, N.; RAES, M.; MICHIELS, C. Antiapoptotic role of HIF-1 and AP-1 in paclitaxel exposed breast cancer cells under hypoxia, Molecular Cancer, v. 9, p. 191, 2010.
13. FOLKMAN, J. Angiogenesis: an organizing principle for drug discovery? Nat Rev Drug Discov, v. 6, n. 4, p. 273-86, 2007.

14. FOX, S. B. et al. The prolyl hydroxylase enzymes are positively associated with hypoxia-inducible factor-1a and vascular endothelial growth factor in human breast cancer and alter in response to primary systemic treatment with epirubicin and tamoxifen. Breast Cancer Research, v. 13, p. 1617, 2011.

15. HYSENI, A.; VAN DER GROEP, P.; VAN DER WALL, E.; VAN DIEST, P. J. Subcellular FIH-1 expression patterns in invasive breast cancer in relation to HIF-1 $\alpha$ expression. Cell Oncol, v. 34, n. 6, p. 565-70, 2011.

16. JOHANNSEN, M. et al. Can tyrosine kinase inhibitors be discontinued in patients with metastatic renal cell carcinoma and a complete response to treatment? A multicentre, retrospective analysis. Eur Urol, v. 55, n. 6 , p. $1430-8,2009$.

17. KOH, M. Y.; SPIVAK-KROIZMAN, T. R.; POWIS, G. Inhibiting the hypoxia response for cancer therapy: the new kid on the block. Clin Cancer Res, v. 15, p. 5945-6, 2009 .

18. LANDO, D. et al. FIH-1 is an asparaginyl hydroxylase enzyme that regulates the transcriptional activity of hypoxia-inducible factor. Genes Dev, v. 16, p.1466-71, 2002.

19. LEE, C. M.; TANNOC, I. F. The distribution of the therapeutic monoclonal antibodies cetuximab and trastuzumab within solid tumors. BMC Cancer, v. 10, p. $255,2010$.

20. LI, J. et al. Knockdown of hypoxia-inducible factor-1alpha in breast carcinoma MCF-7 cells results in reduced tumor growth and increased sensitivity to methotrexate. Biochem Biophys Res Commun, v. 342, p. 1341$51,2006$.

21. RUAN, K.; SONG, G.; OUYANG, G. Role of hypoxia in the hallmarks of human cancer. J Cell Biochem, v. 107, p. 1053-62, 2009.

22. RYU, K.; PARK, C.; JOO-LEE, Y. Hypoxia-inducible factor 1 alpha represses the transcription of the estrogen receptor alpha gene in human breast cancer cells. Biochem Biophys Res Commun, v. 407, p. 831-6, 2011.

23. SANTHANAM, A. N.; BAKER, A. R.; HEGAMYER, G.; KIRSCHMANN, D. A.; COLBURN, N. H. Pdcd4 repression of lysyl oxidase inhibits hypoxia-induced breast cancer cell invasion, Oncogene, v. 29, p. 3921-32, 2010.

24. SARAH, J. C. et al. Antiangiogenic agents increase breast cancer stem cells via the generation of tumor hypoxia. PNAS, v. 109, n. 8, p. 2784-9, 2012. 
25. SOBHANIFAR, S.; AQUINO-PARSONS, C.; STANBRIDGE, E. J.; OLIVE, P. Reduced expression of hypoxia-inducible factor- $1 \alpha$ in perinecrotic regions of solid tumors. Cancer Res, v. 65, p. 7259-66, 2005.

26. TAN, E. Y. et al. Cytoplasmic location of factor-inhibiting hypoxia-inducible factor is associated with an enhanced hypoxic response and a shorter survival in invasive breast cancer, Breast Cancer Res, v. 9, p. R89, 2007.
27. VOSS, M. J. et al. Luminal and basal-like breast cancer cells show increased migration induced by hypoxia, mediated by an autocrine mechanism, $B M C$ Cancer, v. 11, p. 158, 2011.

28. YAMAMOTO, Y. et al. Hypoxia-inducible factor lalpha is closely linked to an aggressive phenotype in breast cancer. Breast Cancer Res Tr, v. 110, n. $465-75,2008$. 